\title{
DINAMICA RĂSPUNSULUI ANTIOXIDATIV LA TOMATELE CU DIFERIT TIP DE INTERACT,IUNE CU AGENTUL VIRAL
}

\author{
Mărîi L., Andronic L., Smerea S., Erhan I.
}

Institutul de Genetică, Fiziologie şi Protecţie a Plantelor, lilimaryi@gmail.com

\begin{abstract}
The defensive response of 4 tomato genotypes to Tobacco Mosaic Virus or Tomato Aspermy Virus was evaluated according to 3 indices - peroxidase and catalase activities and hydrogen peroxide content. The response was differentiated according to the applied viral infection, the genotype and dynamics of the infection process. Particularities have been attested in the reaction of the antioxidative response at different stages of the pathogenesis - increasing or decreasing of the evaluated indices compared to the healthy control.
\end{abstract}

Key words: viral infection, POX, CAT, hydrogen peroxide.

\section{Introducere}

Interacțiunea plantelor cu virusurile fitopatogene se caracterizează prin perturbări profunde, deseori ireversibile exprimate la nivel structural, fiziologic și biochimic. Răspunsurile defensive dezvoltate de plante la infectarea cu agenți virali sunt determinate de mecanisme stabilite evolutiv si au ca menire asigurarea supraviețuirii indivizilor afectați. 
Totodată, răspunsurile plantelor la acţiunea factorilor exogeni pot avea un caracter nediferenţiat prin declanșarea unor reacții nespecifice, precum reacțiile oxidative.

Speciile reactive de oxigen (SRO) sunt produse indispensabile ale proceselor de fotosinteză, fotorespirație și a altor reacții ale metabolismului celular. Pentru atenuarea efectului toxic şi distructiv al SRO plantele au dezvoltat un sistem protectiv antioxidativ, reprezentat prin enzime care au rolul de a menține într-un anumit echilibru cantitatea acestora. Generarea considerabilă a SRO este o parte componentă a răspunsului plantelor în cazul stresului abiotic şi biotic, și reprezintă un element primordial al mecanismului de rezistentă a celulelor [1]. Pe de o parte SRO au efect de izolare a particulelor intruse prin apoptoza celulelor; pe de alta parte, servesc ca mesageri în inducerea reacției sistemice în țesuturile neafectate adiacente și stabilirea unei rezistente sistemice dobândite.

Producerea SRO este specifică în funcție de statutul genotipului. În cazul genotipurilor rezistente are loc sinteza în 2 reprize, a doua fiind cantitativ mai mare, iar în cazul celor sensibile doar într-o singură tură [5]. Sistemul antioxidativ de asemenea ia amploare diferită în funcție de statutul genotipului (rezistent, sensibil), precum și dinamica procesului de infectare [3]. Printre acestea fac parte peroxidazele, enzime ce îndeplinesc funcţii multiple în organismele vii, unul din roluri fiind catalizarea reacţiilor de oxidare a diferitor substraturi organice sau neorganice cu folosirea în calitate de acceptori a diferitor peroxizi. Catalaza, de asemenea joacă un rol important în sistemul antioxidativ, dar spre deosebire de peroxidază, pentru activarea funcţiilor oxidative necesită o concentraţie mai mare de peroxid de hidrogen, dar are şi o viteza mai mare de descompunere a substratului.

Studii în vederea atestării efectelor produse de viroze, în particular a virusului aspermiei tomatelor, virusului mozaicului tutunului la tomate au fost efectuate de mai mulți cercetători. Scopul acestei lucrări include evaluarea comparativă a acestor 2 virusuri în cazul unor sisteme gazdă-patogen cu diferit tip de interacțiune (compatibilă și incompatibilă), incluzând genotipuri cu reacție diferențiată - sensibilitate, toleranță, rezistență.

\section{Materiale şi metode}

Evaluarea reacţiilor defensive a plantelor de tomate la infecţiile virale s-a efectuat în baza a 4 genotipuri cu grad diferit de sensibilitate la VMT: susceptibil - s. Elvira, specia spontană caracterizată prin toleranță S. pimpinellifolium (S.P.) și genotipurile deținătoare de gene de rezistență la VMT - Craigella TM2 (Tm-2²/Tm-2 $\left.{ }^{2}\right)$, Craigella TM1 (Tm-1/Tm-1). La etapa de 4-6 frunzuliţe plantele au fost inoculate cu virusul mozaicului tutunului (VMT) sau virusul aspermiei tomatelor (VAT). Pentru fiecare genotip au fost utilizate 3 loturi: martor plante sănătoase, VMT - plante infectate cu VMT şi VAT - cele cu VAT. Experienţele au fost montate în condiţii de solar.

La diferite etape de la inocularea plantelor (la 14-34 zile post inoculare - ZPI) au fost colectate frunze pentru determinarea activităţii peroxidazei (POX) şi catalazei (CAT). Activitatea peroxidazelor acide (POX) a fost evaluată prin metoda spectrofotometrică în baza modificării dinamice a densităţii optice a extractului (după Boiarchin [8]). La bază a stat viteza de oxidare a benzidinei sub acţiunea peroxidazei ce se conţine în extractul frunzelor plantelor (schimbarea densităţii optice timp de 1 sec la $1 \mathrm{~g}$ de masă vegetativă). În mod similar, activitatea catalazei (CAT) din supernatantul extractelor de frunze a fost determinată în bază descompunerii fermentative a peroxidului de hidrogen [2]. Analiza cantitativă a peroxidului de hidrogen $\left(\mathrm{H}_{2} \mathrm{O}_{2}\right)$ în frunze s-a realizat prin metoda spectrofotometrică conform descrierii după Sergiev [7] în baza reacţiei calitative cu KI. Experimentele au fost realizate în trei repetiţii biologice şi 3 repetiţii analitice. 
Prezența particulelor virale în plantele inoculate a fost confirmată prin intermediul procedeului de contrastare negativă cu ajutorul microscopiei electronice [4].

Prelucrarea datelor a fost efectuată cu ajutorul programelor statistice Statgraphics Plus 5.0. Diferențele statistice semnificative au fost deduse în baza testului F. Prezentarea grafică a fost realizată prin intermediul aplicaţiei Excel.

\section{Rezultate şi discuţii}

Pătrunderea particulelor virale în celule şi producerea procesului infecțios (local sau sistemic) este asistată de un şir de modificări ce presupun reacţii cu răspuns defensiv în vederea reprimării impactului patogenului. Astfel, în urma cercetărilor realizate s-a stabilit că activitatea POX a fost la a 14-ea zi de la inoculare, etapa exteriorizării simptomelor, în creștere de 1,6-4,6 ori față de martor la infectarea cu VAT la 3 din 4 genotipuri analizate, iar la specia spontana SP, dimpotrivă în descreștere de 2,4 ori. Totodată, la a 21 -a ZPI se observă o reacție specifică de atenuare a diferențelor între martor şi lotul infectat la soiul Elvira și scăderea POX la genotipurile TM1 și TM2 (Fig.1).

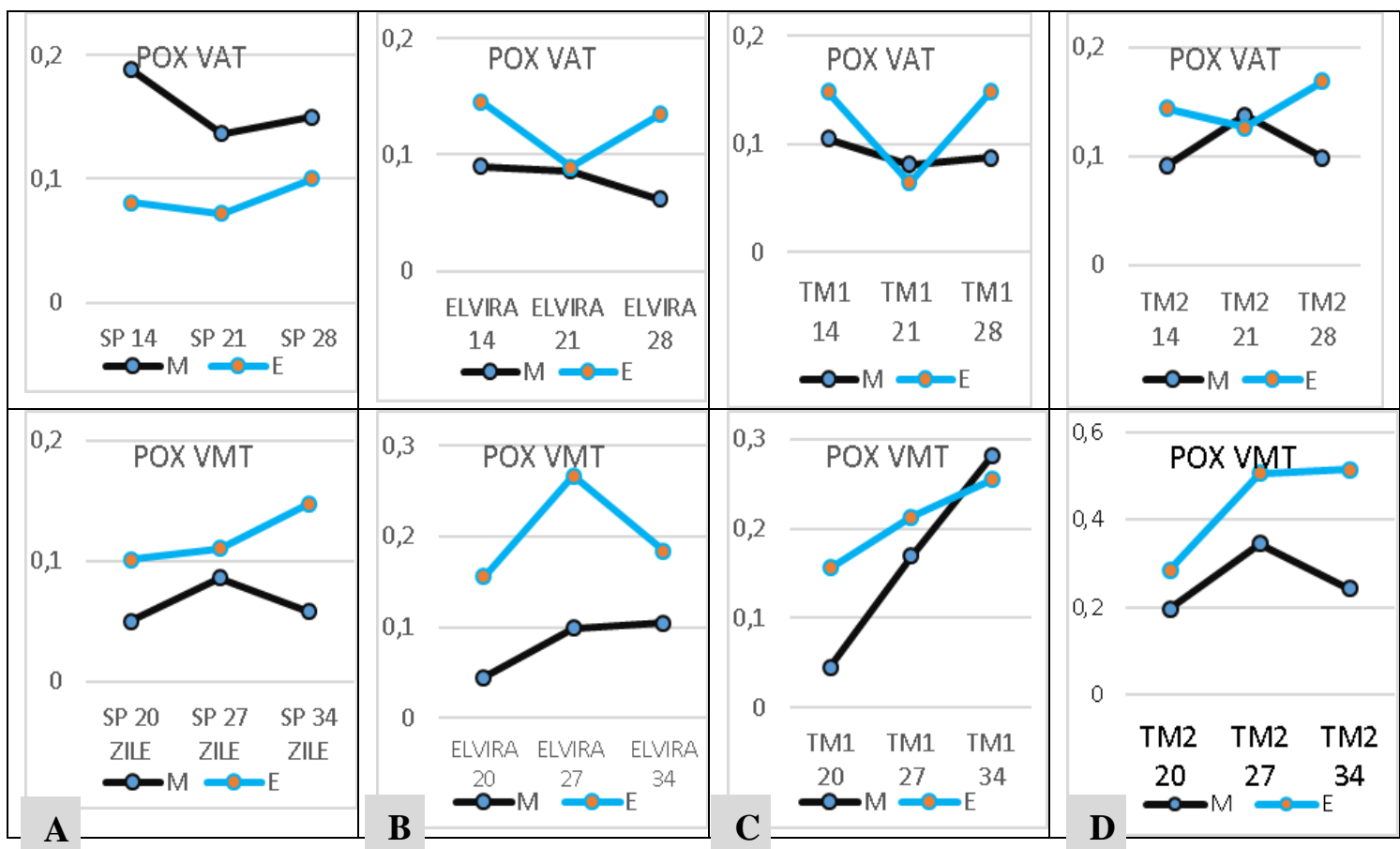

Figura 1. Valorile medii ale indicilor POX (în unităţi convenţionale) în dinamică la infectarea cu VAT sau VMT a 4 genotipuri de tomate: A - S. pimpinellifolium, B - s. Elvira, C Craigella Tm-1/Tm-1, D - Craigella Tm-2 $2 / \mathrm{Tm}-2^{2}$.

Analiza în dinamică a permis să constatăm că, la a 28-a ZPI se observă aceeași tendință în raport cu martorul ca și la a 14-ea ZPI. Specia spontană SP îşi menține o activitate mai scăzută față de martor a POX pe tot parcursul evaluării în cazul infectării cu VAT.

În mod similar, în cazul infectării plantelor cu VMT, s-a constatat mărirea POX de 2 - 7,9 ori față de martor la a 20-ea ZPI, iar tendința dată se menține pe tot parcursul evaluărilor - la a 27-ea şi 34-a ZPI (cu excepţie TM1). În fluctuaţiile dinamice ale POX constatăm un răspuns specific, atât în dependenţă de genotip, cât şi de tipul infecţiei aplicate. Astfel, în majoritatea 
variantelor se atestă diferenţe statistic semnificative după POX între variantele martor şi cele infectate, precum şi între genotipuri. În acelaşi timp, în cazul unor genotipuri, stabilim variaţii cantitative ale POX la diferite etape ale procesului de patogeneză (TM1-VMT sau TM2-VAT la a 21-a şi 27-ea ZPI, respectiv), indicând tendinţe diametral opuse şi diferite faţă de martor în direcția măririi sau diminuării. Este cunoscut, că fluctuațiile indicilor POX la diferite etape ale dezvoltării plantelor este un fenomen imanent. Totuşi, pentru combinaţiile specifice genotip-virus analizate se atestă evoluţii diferite faţă de martor, exprimate prin 2 evocări:

i)Modificările în dinamică dețin aceeași tendință, doar ca amplitudinea variațiilor în variantele infectate sunt semnificativ mai mari (Elvira -VMT, TM2-VMT) sau mai mici (SPVAT) comparativ cu martorul.

ii) La o anumită etapă în dinamica procesului de patogeneză virală are loc reprimarea sau sporirea activități POX comparativ cu plantele martor aflate la aceeași etapă de dezvoltare (Elvira -VAT, TM1-VAT şi TM2-VAT, Elvira -VMT), fapt atestat şi în alte cercetări [6].

În cazul infectării cu VAT valorile POX au fost de regulă mai mici la aceleași genotipuri infectate cu VMT. Cele mai mari valori ale POX au fost stabilite pentru genotipul TM2, atât în cazul infectării cu VMT, cât şi VAT.

CAT. Catalaza, la fel ca şi peroxidazele participă la stabilizarea cantităţii de peroxid de hidrogen din celulă. În sistemele gazdă-patogen analizate, valorile indicilor CAT au exprimat o creștere față de martor de 1,3-6,4 ori la a 15-ea ZPI la toate genotipurile analizare în cazul infectării plantelor cu VAT. Totodată, la a 22-a și 29-a ZPI are loc o atenuare ușoară a diferențelor CAT între variantele martor și cele infectate, și doar la SP se atestă o scădere considerabilă a CAT față de martor (Fig. 2).

Figura 2. Variaţia indicilor CAT şi a conţinutului de peroxid de hidrogen la infectarea genotipurilor de tomate cu VAT sau VMT la diferite etape ale procesului de patogeneză, exprimaţi în unităţi convenţionale.

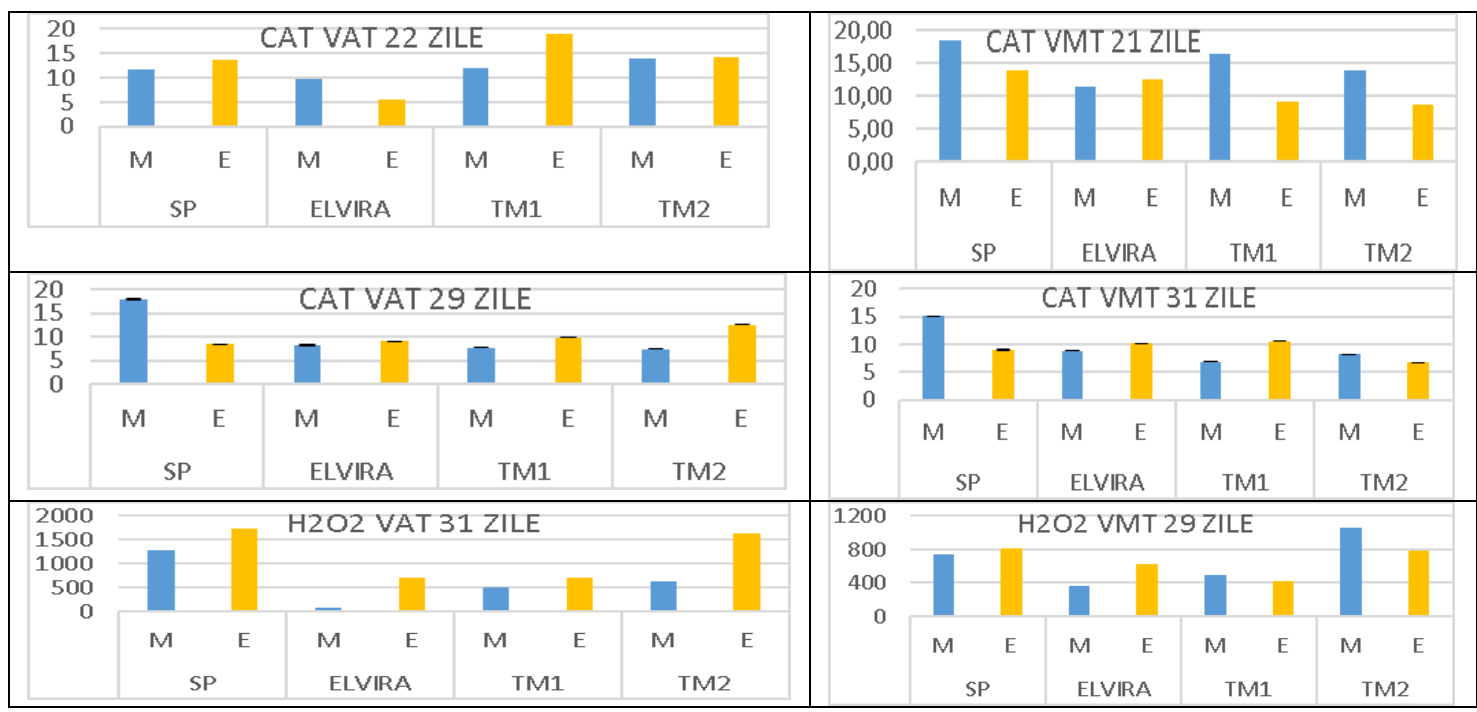

Specia SP și soiul sensibil Elvira la infectare cu VAT mențin tendinţa de exprimare a CAT în raport cu martorul pe parcursul evaluărilor, în timp ce genotipurile TM1 și TM2 au exprimat fluctuații în dinamică. In același timp, infectarea cu VMT a contribuit, dimpotrivă, la o suprimare semnificativă a CAT de 1,3-1,7 ori la a 21-a ZPI la genotipul tolerant și cele 
rezistente TM1 și TM2 (interacţiune incompatibilă) și o creștere a CAT la soiul sensibil Elvira. În toate cazurile analizate sunt stabilite diferenţe statistic semnificative între valorile medii stabilite la martor $(\mathrm{M})$ şi experienţă (E) la nivel de cel puţin $\mathrm{P} \leq 0,05$.

Cele mai mari valori ale CAT se atestă la specia spontană şi genotipurile TM1 și TM2 şi în descreștere la soiul Elvira. Totodată, în cazul infectării cu VAT are loc o creștere graduală în următoarea ordine: Elvira $<$ S.P < TM1 < TM2. În cazul plantelor infectate cu VMT reacția genotipurilor conform amplitudinii modificărilor CAT poate fi descrisă după tendința: TM2 < TM1 < Elvira < S.P.

H2O2. Conținutul $\mathrm{H}_{2} \mathrm{O}_{2}$ a indicat valori mai mari de 1,38-8,08 față de martor la infectarea plantelor cu VAT, cel mai violent reacționând soiul Elvira. În același timp, infectarea plantelor cu VMT a contribuit la micșorarea valorilor $\mathrm{H}_{2} \mathrm{O}_{2}$ de 1,17-5,95 ori față de martor pentru genotipurile cu gene de rezistență TM1 și TM2, şi creșterea concentraţiei pentru genotipul tolerant și sensibil de 1,1 și 1,68 ori, respectiv. Deci, specia spontană și soiul sensibil au avut o

reacție similară atât la infectarea plantelor cu VAT sau VMT, iar genotipurile purtătoare de gene de rezistență au prezentat un răspuns diferențiat după conținutul de $\mathrm{H}_{2} \mathrm{O}_{2}$ în cazul interacțiunilor compatibile (VAT) și cele incompatibile (VMT).

\section{Concluzii}

Infectarea tomatelor cu VAT sau VMT contribuie la modificarea semnificativă a valorilor POX, CAT şi a conţinutului de peroxid de hidrogen în țesuturile plantelor. La etapele incipiente, indicii CAT în cazul infectării cu VMT a genotipurilor rezistente şi tolerant exprimă valori mai mici faţă de martor, iar genotipul sensibil mai mari. În cazul infectării cu VAT, dimpotrivă, are loc creşterea valorilor CAT faţă de martor, cu excepţia genotipului TM2. După conţinutul peroxidului de hidrogen se atestă un răspuns diferenţiat pentru interacţiunile incompatibile (TM1-VMT şi TM2-VMT) exprimat prin micşorarea valorilor faţă de martor şi prin creşterea concentraţiei pentru aceleaşi genotipuri cu interacţiune compatibilă (TM1-VAT și TM2-VAT). Cele mai mari valori ale POX au fost stabilite pentru genotipul TM2, atât în cazul infectării cu VMT, cât şi VAT. În dinamica procesului de patogeneză se atestă fluctuaţii ale activităţii antioxidative (creşterea sau diminuarea la anumite etape), determinate de particularităţile reacției genotipului la infecţie.

\section{Bibliografie}

1. Almagro L., Gómez Ros L., Belchi-Navarro S. et al. Class III peroxidases in plant defense reactions. In: Journal of Experimental Botany, 2009, vol. 60, Issue 2, p. 377-390.

2. Beers R. F. Jr., Sizer I. W. A spectrometric method for measuring the breakdown of hydrogen peroxide by catalase. In: J. Biol. Chem. 1952, vol. 195, p. 133-140.

3. Hernández J., Gábor G. M., Clemente-Moreno J. et al. Oxidative stress and antioxidative responses in plant-virus interactions. In: Physiological and Molecular Plant Pathology. 2016, vol. 94, p. 134-148.

4. Hitchborn, J.H., Hills, G.I. The use of negative staining in the electron microscopic examination of plant viruses in crude extracts. In: Virology. 1965, vol. 27, p. 528-540.

5. Levine A., Tenhaken R., Dixon R. and Lamb C. $\mathrm{H}_{2} \mathrm{O}_{2}$ from the oxidative burst orchestrates the plant hypersensitive disease resistance response. In: Cell, 1994, vol. 79, no. 4, p. 583-593.

6. Matkovics B., Szabo L., Varga S. I. Study of host-parasite interaction in tomato plants. In: Acta Biologica Szeged. 1981, vol. 27(1-4), p. 17-23. 
7. Sergiev I., Alexieva V., Karanov E. Effect of spermine, atrazine and combination between them on some endogenous protective systems and stress markers in plants. In: Compt. Rend. Acad. Bulg. Sci., 1997, 51, p. 121-124.

8. Методы биохимического исследования растений. Ермаков А.И., Арасимович В.В., Ярош Н.П. и др.; Под ред. Ермакова А.И., 3 изд. Л.: Агропромиздат. 1987. 430 c. 